Article

\title{
Characterization and Antimicrobial Activity of Volatile Constituents from Fresh Fruits of Alchornea cordifolia and Canthium subcordatum
}

\author{
Emmanuel E. Essien ${ }^{1, *}$, Jennifer Schmidt Newby ${ }^{2}$, Tameka M. Walker ${ }^{2}$, William N. Setzer ${ }^{2}$ and \\ Olusegun Ekundayo ${ }^{3}$ \\ Received: 17 November 2015; Accepted: 16 December 2015; Published: 29 December 2015 \\ Academic Editors: Lutfun Nahar, Norazah Basar and Satyajit D. Sarker \\ 1 Department of Chemistry, University of Uyo, Akwa Ibom State 520101, Nigeria \\ 2 Department of Chemistry, University of Alabama in Huntsville, Huntsville, AL 35899, USA; \\ jennifer.newby315@gmail.com (J.S.N.); Ivygrad08@yahoo.com (T.M.W.); \\ wsetzer@chemistry.uah.edu (W.N.S.) \\ 3 Department of Chemistry, University of Ibadan, Ibadan 200284, Nigeria; oekundayo@yahoo.com \\ * Correspondence: emmaflowus1@yahoo.co.uk; Tel.: +234-803-368-3424
}

\begin{abstract}
Bacterial resistance has been increasingly reported worldwide and is one of the major causes of failure in the treatment of infectious diseases. Natural-based products, including plant secondary metabolites (phytochemicals), can be exploited to ameliorate the problem of microbial resistance. The fruit essential oils of Alchornea cordifolia and Canthium subcordatum were obtained by hydrodistillation and analyzed by gas chromatography-mass spectrometry (GC-MS). The essential oils were subjected to in vitro antibacterial, antifungal and cytotoxic activity screening. Thirty-eight compounds comprising $97.7 \%$ of $A$. cordifolia oil and forty-six constituents representing $98.2 \%$ of $C$. subcordatum oil were identified. The major components in A. cordifolia oil were methyl salicylate $(25.3 \%)$, citronellol $(21.4 \%), \alpha$-phellandrene $(7.4 \%)$, terpinolene $(5.7 \%)$ and 1,8 -cineole (5.5\%). Benzaldehyde (28.0\%), $\beta$-caryophyllene (15.5\%), $(E, E)-\alpha$-farnesene $(5.3 \%)$ and methyl salicylate $(4.5 \%)$ were the quantitatively significant constituents in C. subcordatum fruit essential oil. A. cordifolia essential oil demonstrated potent in vitro antibacterial activity against Staphylococcus aureus $(\mathrm{MIC}=78 \mu \mathrm{g} / \mathrm{mL})$ and marginal antifungal activity against Aspergillus niger $(\mathrm{MIC}=156 \mu \mathrm{g} / \mathrm{mL})$. C. subcordatum showed antibacterial activity against Bacillus cereus and S. aureus (MIC $=156 \mu \mathrm{g} / \mathrm{mL}$ ) and notable antifungal activity against $A$. niger $(\mathrm{MIC}=39 \mu \mathrm{g} / \mathrm{mL}$ ). However, no appreciable cytotoxic effects on human breast carcinoma cells (Hs 578T) and human prostate carcinoma cells (PC-3) were observed for either essential oil. The antimicrobial activities of $A$. cordifolia and C. subcordatum fruit essential oils are a function of their distinct chemical profiles; their volatiles and biological activities are reported for the first time.
\end{abstract}

Keywords: Alchornea cordifolia; Canthium subcordatum; essential oil composition; antibacterial; antifungal

\section{Introduction}

Antimicrobial resistance is one of the most serious public health threats that results mostly from the selective pressure exerted by antibiotic use and abuse [1,2]. During the last few decades, rapid evolution and spread of resistance among clinically important bacterial species have been observed. Due to this increasing resistance, many antimicrobial agents are losing their efficacy [3-5]. Consequently, the therapeutic options for the treatment of infections have become limited or even unavailable. According to the World Health Organization (WHO), infectious diseases are the second cause of death around the 
world [6]. Therefore, it is necessary to search and develop new alternative compounds to ameliorate the problem of microbial resistance.

Alchornea cordifolia (Schumach. and Thonn.) Müll. Arg. (Euphorbiaceae) is a shrub found along the coastal regions of West Africa. It has multipurpose utilization as fodder, food and medicine. The leaves, roots and stem bark extracts are used extensively in traditional medicine in the preparation of drugs for urinary, respiratory and gastro intestinal disorders [7]. A slurry from the fruits is administered for asthma and cough. The leaves are used internally for the management of gastrointestinal, respiratory and urinary tract infections and externally for wounds. A decoction of the leaves is used as eye lotion [8]. The leaves and stem bark, when powdered, are used in the treatment of ringworms and other skin infections [9]. Hitherto, the leaf part of A. cordifolia has been a subject of scientific studies: anti-microbial, antioxidant and anticancer activities, etc. [10-13]. The gas chromatographic-mass spectral (GC-MS) characterization of the volatile oil from fresh leaves of $A$. cordifolia has been reported [14]. The aqueous extract of $A$. cordifolia has demonstrated antibacterial activity against 21 bacterial strains tested and showed the highest levels of antibacterial activity with MICs against methicillin-resistant Staphylococcus aureus (MRSA) in the range of $1.6-3.1 \mathrm{mg} / \mathrm{mL}$ and MBCs in the range of $6.3-12.5 \mathrm{mg} / \mathrm{mL}$ among 24 other plant species studied [15]. Phyto-constituents, such as steroids, phenolic compounds, flavonoids, flavones, tannins, xanthones and alkaloids, have been isolated from A. cordifolia leaf [16-19].

Canthium subcordatum DC. (formerly Psydrax subcordata DC., Rubiaceae) is a tree that grows in central and western Africa and reaches a height of more than $10 \mathrm{~m}$ [20]. Its roots, leaves and stem bark are used for medicinal purposes. Alcoholic extracts of the stem bark have potential antidiabetic properties [21] and the roots are used to treat malaria fever, inflammation and cardiovascular disease [22]. Recently, five new iridoid dimers were isolated from the fruits of C. subcordatum [23]. A number of iridoids, which include $(6 S, 9 R)$-roseoside [24] and shanzhisin methyl ester gentiobioside [25] have been isolated from the stem-bark of $C$. subcordatum and their structures deduced. GC-MS analysis and anticancer activity of ethanol leaf extract of $C$. parviflorum have also been reported [26,27]. As part of an ongoing search for biologically active essential oils from the rain forest biodiversity of Nigeria, we report the antibacterial and antifungal activities of volatile constituents from the aromatic fresh fruits of A. cordifolia and C. subcordatum.

\section{Experimental Section}

\subsection{Plant Material}

The mature fresh fruits of A. cordifolia and C. subcordatum were collected in the month of July 2004, from the campus of the University of Ibadan, Nigeria. Plant samples were authenticated by F. Usang of the Herbarium Headquarters, Forest Research Institute of Nigeria (FRIN), Ibadan, Nigeria, where voucher specimens (FHI 107409 and FHI 107410, respectively) were deposited.

The fruit essential oils were obtained by hydrodistillation $(4 \mathrm{~h})$ of the pulverized air-dried plant samples $(500 \mathrm{~g})$ in an all glass Clevenger-type apparatus following the British Pharmacopoeia specifications [28]. The fruit oils were dried over sodium sulfate and kept in refrigeration $\left(4^{\circ} \mathrm{C}\right)$ after estimation of percentage yield.

\subsection{Gas Chromatographic_Mass Spectral Analysis}

The essential oils were subjected to GC-MS analysis on an Agilent system consisting of a model 6890 gas chromatograph, a model 5973 mass selective detector (MSD) (Agilent Technologies, Santa Clara, CA, USA), and an Agilent ChemStation data system (http://www.agilent.com/ en-us/products/software-informatics/massspec-workstations/gc-msd-chemstation-software). The GC column was an HP-5ms fused silica capillary with a (5\% phenyl)-methyl polysiloxane stationary phase (30 $\mathrm{m} \times 0.25 \mu \mathrm{m}$ film thickness). The carrier gas was helium with a column head pressure of $7.07 \mathrm{psi}$ and flow rate of $1.0 \mathrm{~mL} / \mathrm{min}$. Inlet temperature was $200{ }^{\circ} \mathrm{C}$ and MSD detector temperature 
was $280{ }^{\circ} \mathrm{C}$. The GC oven temperature program was used as follows: $40{ }^{\circ} \mathrm{C}$ initial temperature, held for $10 \mathrm{~min}$; increased at $3{ }^{\circ} \mathrm{C} / \mathrm{min}$ to $200{ }^{\circ} \mathrm{C}$; increased $2{ }^{\circ} \mathrm{C} / \mathrm{min}$ to $220^{\circ} \mathrm{C}$. The sample was dissolved in $\mathrm{CH}_{2} \mathrm{Cl}_{2}$, and $1 \mu \mathrm{L}$ was injected using a splitless injection technique.

Identification of individual constituents of the essential oils was achieved based on their retention indices (determined with a reference to a homologous series of normal alkanes) and by comparison of their mass spectral fragmentation patterns (National Institute of Standards and Technology, NIST, database/ChemStation data system) and with the literature [29].

\subsection{Antibacterial Screening}

A. cordifolia and C. subcordatum essential oils were screened for antibacterial activity against Bacillus cereus (ATCC No. 14579), Staphylococcus aureus (ATCC No. 29213), Pseudomonas aeruginosa (ATCC No. 27853), and Escherichia coli (ATCC No. 10798). Minimum inhibitory concentrations (MICs) were determined using the micro broth dilution technique [30]. Dilutions of the samples were prepared in cation-adjusted Mueller Hinton broth (CAMHB) beginning with $50 \mu \mathrm{L}$ of $1 \% w / w$ solutions of samples in DMSO plus $50 \mu \mathrm{L}$ CAMHB. The sample solutions were serially diluted (1:1) in CAMHB in 96-well plates to give concentrations of 2500, 1250, 625, 313, 156, 78, 39, and $19.5 \mu \mathrm{g} / \mathrm{mL}$. Organisms at a concentration of approximately $1.5 \times 10^{8}$ colony-forming units (CFU)/mL were added to each well. Plates were incubated at $37^{\circ} \mathrm{C}$ for $24 \mathrm{~h}$; the minimum inhibitory concentration (MIC) was determined as the lowest concentration without turbidity. Gentamicin was used as a positive antibiotic control; DMSO was used as a negative control (50 $\mu \mathrm{L}$ plus $50 \mu \mathrm{L}$ CAMHB, serially diluted as above).

\subsection{Antifungal Screening}

Antifungal activity was determined, as described above for bacteria (i.e., serial dilution, concentrations of 2500, 1250, 625, 313, 156, 78, 39, and $19.5 \mu \mathrm{g} / \mathrm{mL}$ ) using Candida albicans (ATCC No. 10231) in a yeast-nitrogen base growth medium with approximately $7.5 \times 10^{7} \mathrm{CFU} / \mathrm{mL}$. Amphotericin B was used as the positive control. An additional test for antifungal activity against Aspergillus niger (ATCC No. 16888) was determined as above using yeast mold (YM) broth inoculated with $A$. niger hyphal culture diluted to a McFarland turbidity of 1.0. Amphotericin B was the positive control.

\subsection{Cell Culture}

Human Hs578T breast ductal carcinoma cells (ATCC No. HTB-129) [31] were grown in a 3\% $\mathrm{CO}_{2}$ environment at $37^{\circ} \mathrm{C}$ in Dulbecco's modified Eagle medium (DMEM) with $4500 \mathrm{mg}$ glucose per liter of medium, supplemented with $10 \%$ fetal bovine serum, $10 \mu \mathrm{g}$ bovine insulin, 100,000 units penicillin and $10.0 \mathrm{mg}$ streptomycin per liter of medium, and buffered with $44 \mathrm{mM} \mathrm{NaHCO}, \mathrm{pH} 7.35$.

Human PC-3 prostatic carcinoma cells (ATCC No. CRL-1435) [32] were grown in a $3 \% \mathrm{CO}_{2}$ environment at $37^{\circ} \mathrm{C}$ in RPMI-1640 medium with l-glutamine, supplemented with $10 \%$ fetal bovine serum, 100,000 units penicillin and $10.0 \mathrm{mg}$ streptomycin per liter of medium and buffered with $15 \mathrm{mM}$ Hepes and $23.6 \mathrm{mM} \mathrm{NaHCO}_{3}, \mathrm{pH} 7.30$.

\subsection{Cytotoxicity Screening}

Hs 578T cells were plated into 96-well cell culture plates at $1.0 \times 10^{5}$ cells per well and PC-3 cells at $1.9 \times 10^{4}$ cells per well. The volume in each well was $100 \mu \mathrm{L}$ for both cell types. After $48 \mathrm{~h}$, supernatant fluid was removed by suction and replaced with $100 \mu \mathrm{L}$ growth medium containing either 2.5 or $1.0 \mu \mathrm{L}$ of dimethylsulfoxide (DMSO) solution of oils (1\% $w / w$ in DMSO), giving a final concentration of 250 or $100 \mu \mathrm{g} / \mathrm{mL}$, respectively, for each oil. Hs 578T cells were tested with final concentrations at $250 \mu \mathrm{g} / \mathrm{mL}$ and PC-3 at final concentration of $100 \mu \mathrm{g} / \mathrm{mL}$. Solutions were added to wells in four replicates. Medium controls and DMSO controls ( 25 or $10 \mu \mathrm{L}$ DMSO/mL) were used. Tingenone (250 or $100 \mu \mathrm{g} / \mathrm{mL}) \mathrm{was}$ used as a positive control [33]. After the addition of the sample, plates were incubated for $48 \mathrm{~h}$ at $37^{\circ} \mathrm{C}$; medium was then removed by suction, and $100 \mu \mathrm{L}$ of fresh medium was added to each well. In order 
to establish percent kill rates, the Cell Titer $96{ }^{\circledR} \mathrm{AQ}$ ueous Non-Radioactive Cell Proliferation assay was performed [34]. After colorimetric readings were recorded (using a Molecular Devices SpectraMAX Plus microplate reader, $490 \mathrm{~nm}$, Molecular Devices, LLC, Sunnyvale, CA, USA), average absorbances, standard deviations and percent kill ratios $\left(\% \mathrm{kill}_{\mathrm{oil}} / \%\right.$ kill $\left.\mathrm{DMSO}\right)$ were calculated.

\section{Results and Discussion}

The relative concentrations of the volatile components in A. cordifolia and C. subcordatum fruits, according to their elution order on HP-5ms capillary column are presented in Tables 1 and 2 respectively. The aromatic fruit essential oils were obtained in $0.17 \%(w / w)$ yield. Thirty-eight compounds comprising $97.7 \%$ of $A$. cordifolia oil and forty-six constituents representing $98.2 \%$ of $C$. subcordatum oil were identified. The fruit essential oil of $A$. cordifolia consisted of oxygenated monoterpenoids and aromatic esters ( $52.9 \%$ and $26.5 \%)$, monoterpene and sesquiterpene hydrocarbons $(17.2 \%$ and $14.6 \%)$ and low amounts of aliphatic alcohol and aldehyde (3.7\%). The major components identified in this sample include methyl salicylate $(25.3 \%)$, citronellol (21.4\%), $\alpha$-phellandrene $(7.4 \%)$, terpinolene $(5.7 \%)$ and 1,8-cineole (5.5\%). Other minor constituents detected in considerable quantities were $p$-cymene (3.6\%), $\alpha$-humulene (3.0\%), $\beta$-caryophyllene (2.8\%) $(E)$ - $\beta$-damascenone $(2.0 \%)$ and 1-octen-3-ol $(2.0 \%)$. Two uncommon essential oil constituents were identified as (Z)-rose oxide and geosmin in A. cordifolia essential oil. (Z)-Rose-oxide (isobutenyl-4-methyl tetrahydropyran) is a perfumery ingredient and a constituent (inter alia) of Pelargonium essential oils and secretions of Aromia moschata [35]. This cyclic monoterpene ether, found in $0.5 \%$ concentration in rose oil, is said to be responsible for the highly volatile floral-green top note [36]. Geosmin (1,10-dimethyl-9-decalol), detected in 1.0\% concentration, is reported as a microbial volatile organic compound. Geosmin is described as a powerful aromatic compound with an earthy smell and is implicated as one of the consequences of rot on grapes. It has very low odor threshold and strong odors. Microorganisms such as fungi and bacteria (Actinomycetes, Streptomyces riseus and Streptomyces odourifer) are reported to be present on some fruits, grapes for example, and are known for their ability to produce geosmin during metabolism [37]. According to Dionigi et al. [38], geosmin is derived from a sesquiterpene precursor such as farnesyl pyrophosphate. The major constituents of the fresh leaf essential oil of $A$. cordifolia reported by Okoye et al. [14] were eugenol $(41.7 \%)$, cadinol $(2.46 \%)$, linalool $(30.6 \%)$, caryophyllene $(1.04 \%)$ and $(E)$ - $\alpha$-bergamotene (4.54\%). Twenty-five constituents consisting $90.3 \%$ of the composition of the leaf essential oil were identified in $0.13 \% w / w$ yield.

Benzaldehyde (28.0\%), $\beta$-caryophyllene (15.5\%), $(E, E)$ - $\alpha$-farnesene $(5.3 \%)$ and methyl salicylate (4.5\%) were the quantitatively significant constituents in C. subcordatum fruit essential oil. C. subcordatum fruit oil is comprised of $41.3 \%$ hydrocarbons and $56.9 \%$ oxygen-containing compounds. The five classes of organic compounds identified and reported are twenty-four hydrocarbons (41.3\%), twelve alcohols $(18.6 \%)$, three aldehydes $(28.7 \%)$, four aromatic esters $(5.8 \%)$, one ketone and one ether $(3.8 \%)$. The fruit volatile oil is dominated by sesquiterpenoid compounds $(50.8 \%)$, followed by aromatic compounds (33.8\%), monoterpenoid compounds (7.3\%), simple aldehydes and alcohols $(6.3 \%)$. The monoterpenoid profile consisted of two monoterpene hydrocarbons $(2.8 \%)$ and six oxygenated monoterpenes (4.5\%). Twenty-two sesquiterpene hydrocarbons and seven oxygenated sesquiterpenes made up the sesquiterpenoid profile of the oil. Two unusual sesquiterpenoids, $\alpha$-calacorene and longiborneol were identified in C. subcordatum fruit oil. The sesquiterpene alcohol, longiborneol is a constituent of Juniperus, Pinus, Cupressus, Dacrydium species and Cedrus deodara. It is reported to be a plant growth regulator (inhibits cress root growth and promotes wheat germination) [35]. A literature search has revealed no previous work on the analyses of volatile components of this plant or other Canthium species. The high concentration of benzaldehyde in essential oil samples has been reported by other workers. Lei et al. [39] showed that essential oils from fresh flowers of Cerasus subhirtella and C. serrulata contain $31.2 \%$ and $42.1 \%$ benzaldehyde, respectively as major constituents. Benzaldehyde $(96.96 \%)$ was also indicated as a major component in the leaf essential oil of Prunus myrtifolia [40]. 
Table 1. Chemical composition of Alchornea cordifolia fruit essential oil.

\begin{tabular}{|c|c|c|c|c|}
\hline $\mathbf{R I}^{\mathrm{a}}$ & $\mathbf{R I}^{b}$ & Compound ${ }^{c, d}$ & Area \% & $\mathrm{QI}^{\mathrm{e}} \%$ \\
\hline 855 & 854 & (E)-2-Hexenal & 1.7 & 97 \\
\hline 940 & 939 & $\alpha$-Pinene & 0.5 & 95 \\
\hline 982 & 978 & 1-Octen-3-ol & 2.0 & 89 \\
\hline 1003 & 1005 & $\alpha$-Phellandrene & 7.4 & 94 \\
\hline 1023 & 1026 & $p$-Cymene & 3.6 & 95 \\
\hline 1031 & 1033 & 1,8-Cineole & 5.5 & 98 \\
\hline 1086 & 1088 & Terpinolene & 5.7 & 98 \\
\hline 1111 & 1111 & (Z)-Rose oxide & 0.6 & 93 \\
\hline 1194 & 1190 & Methyl salicylate & 25.3 & 95 \\
\hline 1221 & 1228 & Nerol & 0.8 & 96 \\
\hline 1229 & 1228 & Citronellol & 21.4 & 97 \\
\hline 1244 & 1240 & Neral & 0.7 & 96 \\
\hline 1247 & - & Isogeraniol & 1.6 & 94 \\
\hline 1258 & 1255 & Geraniol & 1.9 & 91 \\
\hline 1272 & 1270 & Geranial & 1.0 & 95 \\
\hline 1375 & 1376 & $\alpha$-Copaene & 0.9 & 99 \\
\hline 1385 & 1380 & $(E)$ - $\beta$-Damascenone & 2.0 & 96 \\
\hline 1392 & 1391 & $\beta$-Elemene & 0.4 & 95 \\
\hline 1405 & - & Geosmin & 1.0 & 95 \\
\hline 1408 & 1409 & $\alpha$-Gurjunene & 0.3 & 99 \\
\hline 1418 & 1418 & $\beta$-Caryophyllene & 2.8 & 99 \\
\hline 1428 & 1426 & $\alpha-(E)$-Ionone & 0.2 & 97 \\
\hline 1452 & 1454 & $\alpha$-Humulene & 3.0 & 99 \\
\hline 1459 & 1461 & Alloaromadendrene & 0.3 & 99 \\
\hline 1480 & 1480 & Germacrene D & 0.4 & 97 \\
\hline 1484 & 1485 & $\beta$-Selinene & 0.7 & 99 \\
\hline 1495 & 1494 & Bicyclogermacrene & 0.4 & 93 \\
\hline 1509 & 1508 & $(E, E)-\alpha$-Farnesene & 0.3 & 89 \\
\hline 1523 & 1524 & $\delta$-Cadinene & 0.9 & 99 \\
\hline 1541 & 1542 & $\alpha$-Calacorene & 0.2 & 98 \\
\hline 1564 & 1564 & (E)-Nerolidol & 0.6 & 87 \\
\hline 1579 & 1581 & Caryophyllene oxide & 1.1 & 98 \\
\hline 1585 & 1583 & (E)-2-Hexenyl benzoate & 0.9 & 97 \\
\hline 1617 & 1619 & 10-epi- $\gamma$-Eudesmol & 0.5 & 98 \\
\hline 1628 & 1627 & 1-epi-Cubenol & 0.3 & 90 \\
\hline 1642 & 1642 & Cubenol & 0.2 & 93 \\
\hline 1683 & 1683 & $\alpha$-Bisabolol & 0.3 & 94 \\
\hline 1759 & 1762 & Benzyl benzoate & 0.3 & 96 \\
\hline
\end{tabular}

${ }^{a}$ RI, calculated retention indices; ${ }^{b}$ RI, retention index from literature; ${ }^{c}$ Order of elution on HP-5ms capillary column; ${ }^{\mathrm{d}}$ Identification by comparison of the mass spectral and retention index data; ${ }^{\mathrm{e}} \mathrm{QI}$, "quality index", reflects the fit comparison of experimental mass spectrum and National Institute of Standards and Technology (NIST) library spectrum. 
Table 2. Chemical composition of Canthium subcordatum fruit essential oil.

\begin{tabular}{|c|c|c|c|c|}
\hline $\mathrm{RI}^{\mathrm{a}}$ & $\mathbf{R I}^{b}$ & Compound ${ }^{c, d}$ & Area \% & $\mathrm{QI}^{\mathrm{e}} \%$ \\
\hline 855 & 854 & (E)-2-Hexenal & 0.4 & 90 \\
\hline 940 & 939 & $\alpha$-Pinene & 1.0 & 96 \\
\hline 966 & 961 & Benzaldehyde & 28.0 & 95 \\
\hline 982 & 978 & 1-Octen-3-ol & 4.4 & 92 \\
\hline 998 & 993 & 3-Octanol & 1.2 & 83 \\
\hline 1025 & 1026 & $p$-Cymene & 1.8 & 93 \\
\hline 1031 & 1033 & 1,8-Cineole & 1.1 & 98 \\
\hline 1102 & 1098 & Linalool & 2.0 & 94 \\
\hline 1175 & 1171 & Nonanol & 0.3 & 94 \\
\hline 1194 & 1190 & Methyl salicylate & 4.5 & 95 \\
\hline 1218 & 1218 & $\beta$-Cyclocitral & 0.3 & 94 \\
\hline 1234 & 1235 & Thymol methyl ether & 0.1 & 96 \\
\hline 1257 & 1255 & Geraniol & 0.8 & 87 \\
\hline 1350 & 1351 & $\alpha$-Cubebene & 0.7 & 99 \\
\hline 1376 & 1376 & $\alpha$-Copaene & 2.9 & 99 \\
\hline 1384 & 1384 & $\beta$-Bourbonene & 1.1 & 98 \\
\hline 1391 & 1390 & $\beta$-Cubebene & 0.4 & 99 \\
\hline 1393 & 1391 & $\beta$-Elemene & 0.5 & 97 \\
\hline 1398 & 1398 & Cyperene & 0.2 & 90 \\
\hline 1410 & 1409 & $\alpha$-Gurjunene & 0.3 & 99 \\
\hline 1418 & 1418 & $\beta$-Caryophyllene & 15.5 & 99 \\
\hline 1429 & 1432 & Calarene & 0.5 & 92 \\
\hline 1437 & 1436 & $\alpha$-Bergamotene & 0.1 & 95 \\
\hline 1439 & 1439 & $\alpha$-Guaiene & 0.2 & 99 \\
\hline 1453 & 1454 & $\alpha$-Humulene & 1.2 & 99 \\
\hline 1456 & - & Nerylacetone & 0.2 & 95 \\
\hline 1460 & 1458 & $(E)$ - $\beta$-Farnesene & 0.1 & 91 \\
\hline 1468 & 1469 & Drima-7,9(11)-diene & 0.4 & 97 \\
\hline 1478 & 1477 & $\gamma$-Muurolene & 1.1 & 99 \\
\hline 1482 & 1480 & Germacrene D & 2.1 & 98 \\
\hline 1486 & 1485 & $\beta$-Selinene & 1.3 & 99 \\
\hline 1496 & 1491 & Valencene & 1.3 & 92 \\
\hline 1501 & 1499 & $\alpha$-Muurolene & 0.8 & 98 \\
\hline 1511 & 1508 & $(E, E)-\alpha$-Farnesene & 5.3 & 95 \\
\hline 1524 & 1524 & $\delta$-Cadinene & 2.1 & 99 \\
\hline 1543 & 1542 & $\alpha$-Calacorene & 0.4 & 91 \\
\hline 1567 & 1564 & (E)-Nerolidol & 0.8 & 91 \\
\hline 1572 & 1570 & (Z)-3-Hexenyl benzoate & 0.5 & 98 \\
\hline 1583 & 1581 & Caryophyllene oxide & 3.5 & 90 \\
\hline 1586 & 1583 & (E)-2-Hexenyl benzoate & 0.4 & 90 \\
\hline 1596 & 1592 & Longiborneol & 2.3 & 98 \\
\hline 1629 & 1627 & 1-epi-Cubenol & 1.3 & 87 \\
\hline 1643 & 1642 & Cubenol & 0.9 & 95 \\
\hline 1648 & 1645 & Torreyol (= $\alpha$-Murrolol) & 1.9 & 93 \\
\hline 1656 & 1653 & $\alpha$-Cadinol & 1.6 & 83 \\
\hline 1760 & 1762 & Benzyl benzoate & 0.4 & 98 \\
\hline
\end{tabular}

a RI, calculated retention indices; ${ }^{\mathrm{b}} \mathrm{RI}$, retention index from literature; ${ }^{\mathrm{c}}$ Order of elution on HP-5ms capillary column; ${ }^{\mathrm{d}}$ Identification by comparison of the mass spectral and retention index data; $\mathrm{e}$ QI, "quality index", reflects the fit comparison of experimental mass spectrum and NIST library spectrum.

The antibacterial and antifungal activities of the fruit volatile oils of $A$. cordifolia and C. subcordatum showed promising antimicrobial activity (Table 3). Alchornea cordifolia oil demonstrated good antibacterial activity against the Gram-positive organism S. aureus (MIC $=78 \mu \mathrm{g} / \mathrm{mL}$ ) and moderate antifungal activity against $A$. niger $(\mathrm{MIC}=156 \mu \mathrm{g} / \mathrm{mL}$ ); $C$. subcordatum oil exhibited moderate antibacterial activity against $B$. cereus and $S$. aureus $(\mathrm{MIC}=156 \mu \mathrm{g} / \mathrm{mL}$ ) and good antifungal activity (MIC $=39 \mu \mathrm{g} / \mathrm{mL}$ ) against $A$. niger. It has been documented that Gram-positive bacteria are more 
sensitive to chemical compounds than Gram-negative bacteria due to differences in the structures of their cell walls; Gram-negative bacteria are less susceptible to hydrophobic small molecules such as essential oil components due to hydrophilic lipopolysaccharides in their outer membrane [41]. This is obvious by the sensitivity of the Gram-positive bacteria to the tested essential oils in the assay; however with differences in the degree of inhibition. The antimicrobial activities observed in the studied fruit essential oils can be attributed to the major constituents or a synergy between the major and some minor compounds. Consistent with the results of $A$. cordifolia essential oil, Laportea aestuans essential oil, rich in methyl salicylate $(54.50 \%)$, has been shown to exhibit antimicrobial activity against $S$. aureus, B. subtilis, P. aeruginosa, E. coli and C. albicans at $200 \mathrm{mg} / \mathrm{mL}$ compared to the standard drug; however, it was more active against the fungi Rhizopus stolon and A. niger at $25 \mathrm{mg} / \mathrm{mL}$ [42]; Pelargonium graveolens essential oil, dominant in citronellol (26.7\%), inter alia, and citronellol, also demonstrated strong inhibitory activity against $S$. aureus and E. coli $[43,44]$. Similarly, benzaldehyde $(96.96 \%$ and $90.6 \%$, respectively, in P. myrtifolia and apricot, Prunus armeniaca, seed essential oils) exhibited antimicrobial activity against S. aureus, S. epidermidis, B. subtilis, P. aeruginosa, E. coli and C. albicans $[39,40]$. Additionally, Stachys cretica essential oil ( $\beta$-caryophyllene, $51.0 \%$ ) and $\beta$-caryophyllene are reported to exhibit strong antimicrobial activity, particularly against $P$. aeruginosa and B. subtilis [45].

Table 3. Antimicrobial activity of A. cordifolia and C. subcordatum fruit volatile oils (MIC, $\mu \mathrm{g} / \mathrm{mL}$ ).

\begin{tabular}{ccccccc}
\hline Sample & B.c & S.a & E.c & P.a & C.a & A.n \\
\hline A. cordifolia & 625 & 78 & 625 & 625 & 625 & 156 \\
C. subcordatum & 156 & 156 & 625 & 625 & 625 & 39 \\
Positive control & $1.22^{\text {a }}$ & $0.61^{\text {a }}$ & $2.44^{\text {a }}$ & $1.22^{\text {a }}$ & $0.61^{\mathrm{b}}$ & $0.61^{\mathrm{b}}$
\end{tabular}

B.c., Bacillus cereus (ATCC No. 14579); S.a, Staphylococcus aureus (ATCC No. 29213); E.c, Escherichia coli (ATCC No. 25922); P.a, Pseudomonas aeroginosa (ATCC No. 27853); C.a, Candida albicans (ATCC No. 10231); A.n, Aspergillus niger (ATCC No. 16401); ${ }^{a}$ Gentamicin sulfate; ${ }^{b}$ Amphotericin B; Negative control, DMSO had zero effect.

Both A. cordifolia and C. subcordatum fruit essential oils were screened for in vitro cytotoxic activity against Hs 578T human breast adenocarcinoma and PC-3 human prostatic carcinoma cells. Neither oil showed activity, however, with $0 \%$ kill at the concentrations tested.

\section{Conclusions}

The antimicrobial activities of $A$. cordifolia and C. subcordatum essential oils are a function of their distinct chemical profiles. The fruit essential oil of $A$. cordifolia, rich in methyl salicylate and citronellol, showed antibacterial activity against $S$. aureus and antifungal activity against $A$. niger. The antimicrobial activity can be attributed to these two major components, which have shown antimicrobial activities [46-48]. C. subcordatum fruit oil was active against B. cereus, S. aureus, and $A$. niger, but the activity is not likely due to the major component benzaldehyde, which is generally not antimicrobial [49], but rather a synergism between minor essential oil components. The promising antimicrobial activities of $A$. cordifolia and C. subcordatum essential oils are consistent with traditional uses of these medicinal plants.

Acknowledgments: William N. Setzer is grateful to an anonymous private donor for the gift of the GC-MS instrumentation.

Author Contributions: Emmanuel E. Essien and Olusegun Ekundayo conceived and designed the project; Emmanuel E. Essien collected and hydrodistilled the essential oils; Jennifer S. Newby and Tameka M. Walker performed the bioactivity assays; William N. Setzer analyzed the data; Emmanuel E. Essien and William N. Setzer wrote the manuscript.

Conflicts of Interest: The authors declare no conflict of interest. 


\section{References}

1. Bérdy, J. Thoughts and facts about antibiotics: Where we are now and where we are heading. J. Antibiot. 2012, 65, 385-395. [CrossRef] [PubMed]

2. French, G.L. The continuing crisis in antibiotic resistance. Int. J. Antimicrob. Agents 2010, 36, S3-S7. [CrossRef]

3. Pitout, J.D.; Laupland, K.B. Extended-spectrum $\beta$-lactamase-producing Enterobacteriaceae: An emerging public-health concern. Lancet Infect. Dis. 2008, 8, 159-166. [CrossRef]

4. Berger, J.; Diab-Elschahawi, M.; Blacky, A. A matched prospective cohort study on Staphylococcus aureus and Escherichia coli blood stream infections: Extended perspectives beyond resistance. Am. J. Infect. Cont. 2010, 38, 839-845. [CrossRef] [PubMed]

5. David, M.Z.; Daum, R.S. Community-associated methicillin-resistant Staphylococcus aureus: Epidemiology and clinical consequences of an emerging epidemic. Clin. Microbiol. Rev. 2010, 23, 616-687. [CrossRef] [PubMed]

6. Mathers, C.; Fat, D.M.; Boerma, J. The Global Burden of Disease: 2004 Update; World Health Organization: Geneva, Switzerland, 2008.

7. Ayensu, E.S. Medicinal Plants of West Africa; Reference Publications, Inc.: Algonac, MI, USA, 1978; pp. $117-121$.

8. Iwu, M.M. Handbook of Africa Medicinal Plants; Conservation International: NewYork, NY, USA, 1993.

9. Burkill, H.M. The Useful Plants of West Tropical Africa; Royal Botantic Gardens: Kew, UK, 1994; Volume 2.

10. Ebi, G.C. Antimicrobial activities of Alchornea cordifolia. Fitoterapia 2001, 72, 69-72. [CrossRef]

11. Cai, Y.; Luo, Q.; Sun, M.; Corke, H. Antioxidant activity and phenolic compounds of 112 traditional Chinese medicinal plants associated with anti-cancer. Life Sci. 2004, 74, 2157-2184. [CrossRef] [PubMed]

12. Olaleye, M.T.; Kolawole, A.O.; Ajele, J.O. Antioxidant properties and glutathione $S$-transferases inhibitory activity of Alchornea cordifolia leaf extract in acetaminophen-induced liver injury. Iran. J. Pharmacol. Ther. 2007, 6, 63-66.

13. Akpo, C.O.; Owhe-Ureghe, U.B. Effect of fresh leaf and stem pith extracts of Alchornea cordifolia on oral bacteria. Biosci. Biotechnol. Res. Asia 2013, 10, 55-59. [CrossRef]

14. Okoye, F.B.C.; Osadebe, P.O.; Okoye, N.N.; Ukwueze, N.N.; David, E. The GC/MS characterization of the volatile oil from fresh leaves of Alchornea cordifolia leaves. Planta Med. 2009, 75, 135-137. [CrossRef]

15. Pesewu, G.; Cutler, R.R.; Humber, D.P. Antibacterial activity of plants used in traditional medicines of Ghana with particular reference to MRSA. J. Ethnopharmacol. 2008, 116, 102-111. [CrossRef] [PubMed]

16. Ogunlana, E.O.; Ramstand, E. Investigations into the antibacterial activities of local plants. Planta Med. 1975, 27, 354-360. [CrossRef] [PubMed]

17. Ogungbamila, F.O.; Samuelson, G. Smooth muscle relaxing flavonoids from Alchornea cordifolia (leaves). Acta Pharmaceut. Nord. 1990, 2, 421-422.

18. Gui, Y.C.; Jun, Y.L.; Ren, X.T. A new antimicrobial flavonol glycoside from Alchornea davidii. Chin. Chem. Lett. 2003, 14, 179-180.

19. Okwu, D.E.; Ukanwa, N. Isolation, characterization and antibacterial activity screening of anthocyanidine glycosides from Alchornea cordifolia (Schumach. and Thonn.) Mull. Arg. leaves. Eur. J. Chem. 2010, 7, 41-48. [CrossRef]

20. Irvine, F.R. Woody Plants of Ghana; Oxford University Press: London, UK, 1961; p. 658.

21. Ampofo, O. Plants that heal. World Health 1977, 247, 26-30.

22. Awah, F.M.; Uzoegwu, P.N.; Ifeonu, P.; Oyugi, J.O.; Rutherford, J.; Yao, X.J.; Fehrmann, F.; Fowke, K.R.; Eze, M.O. Free radical scavenging activity, phenolic contents and cytotoxicity of selected Nigerian medicinal plants. Food Chem. 2012, 13, 1279-1286. [CrossRef]

23. Joubouhi, C.; Mabou, F.D.; Tebou, P.L.F.; Ngnokam, D.; Harakat, D.; Voutquenne-Nazabadioko, L. Five new iridoïd dimers from the fruits of Canthium subcordatum DC (syn. Psydrax subcordata DC). Phytochem. Lett. 2015, 13, 348-354. [CrossRef]

24. Achenbach, H.; Waibel, R.; Raffelsberger, B.; Addae-Mensah, I. Iridoid and other constituents of Canthium subcordatum. Phytochemistry 1981, 20, 1591-1595. [CrossRef]

25. Achenbach, H.; Waibel, R.; Addae-Mensah, I. Shanzhisin methyl ester gentiobioside, a new iridoid-isolation and synthesis. Tetrahedron Lett. 1980, 21, 3677-3678. [CrossRef] 
26. Purushoth, P.T.; Panneerselvam, P.; Selvakumari, S.; Sivaraman, D. In vitro and in vivo anticancer activity of ethanolic extract of Canthium parviflorum Lam on DLA and Hela cell lines. Int. J. Drug Dev. Res. 2011, 3, 280-285.

27. Purushoth, P.T.; Panneerselvam, P.; Suresh, R.; Clement, A.W.; Balasubramanian, S. GC-MS analysis of ethanolic extract of Canthium parviflorum Lamk leaf. J. Appl. Pharm. Sci. 2013, 3, 166-168. [CrossRef]

28. Medicines and Healthcare products Regulatory Agency (MHRA). British Pharmacopoeia, Vol. II; H.M. Stationery Office, Pharmaceutical Press: London, UK, 1980.

29. Adams, R.P. Identification of Essential Oil Components by Gas Chromatography/Mass Spectrometry, 4th ed.; Allured Publishing Corp.: Carol Stream, IL, USA, 2007.

30. Sahm, D.H.; Washington, J.A. Antibacterial susceptibility tests: Dilution methods. In Manual of Clinical Microbiology, 5th ed.; Balows, A., Hausler, W.J., Herrmann, K.L., Isenberg, H.D., Shamody, H.J., Eds.; American Society for Microbiology: Washington, DC, USA, 1991.

31. Hackett, A.J.; Smith, H.S.; Springer, E.L.; Owens, R.B.; Nelson-Rees, W.A.; Riggs, J.L.; Gardner, M.B. Two syngeneic cell lines from human breast tissues: The aneuploid mammary epithelial (Hs578T) and the diploid myoepithelial (Hs578Bst) cell lines. J. Natl. Cancer Inst. 1977, 58, 1795-1806. [PubMed]

32. Kaighn, M.E.; Narayan, K.S.; Ohnuki, Y.; Lechner, J.F.; Jones, L. Establishment and characterization of a human prostatic carcinoma cell line (PC-3). Investig. Urol. 1979, 17, 16-23. [PubMed]

33. Setzer, W.N.; Setzer, M.C.; Hopper, A.L.; Moriarity, D.M.; Lehrman, G.K.; Niekamp, K.L.; Morcomb, S.M.; Bates, R.B.; McClure, K.J.; Stessman, C.C.; et al. The cytotoxic activity of a Salacia liana species from Monteverde, Costa Rica, is due to a high concentration of tingenone. Planta Med. 1998, 64, 583. [CrossRef] [PubMed]

34. Promega Technical Bulletin \# 245. In Cell Titer $96^{\circledR}$ AQueous One Solution Cell Proliferation Assay; Promega Corporation: Madison, WI, USA, 1996.

35. Connolly, J.D.; Hill, R.A. Dictionary of Terpenoids; Chapman and Hall: New York, NY, USA, 2003.

36. Ohloff, C. Scent and Fragrances. In The Fascination of Odours and their Chemical Perspectives; Springer-Verlag: Heidelberg, Germany, 1994.

37. Guerche, S.L.; Chamount, D.B.; Dubourdieu, D.; Darriet, P. Origin of (-)-geosmin on grapes: On the complementary action of two fungi, Botrytis cinerea and Penicillium expansum. Antonie Van Leeuwanhoek 2005, 88, 131-139. [CrossRef] [PubMed]

38. Dionigi, C.P.; Millie, D.F.; Spanier, A.M.; Johnson, P.B. Spore and geosmin production by Streptomyces tendae in several media. J. Agric. Food Chem. 1992, 40, 122-125. [CrossRef]

39. Lee, H.H.; Ahn, J.H.; Kwon, A.R.; Lee, E.S.; Kwak, J.H.; Min, Y.H. Chemical composition and antimicrobial activity of the essential oil of apricot seed. Phytother. Res. 2014, 28, 1867-1872. [CrossRef] [PubMed]

40. Weber, L.D.; Pinto, F.G.; Scur, M.C.; de Souza, J.G.; Costa, W.F.; Leite, C.W. Chemical composition and antimicrobial and antioxidant activity of essential oil and various plant extracts from Prunus myrtifolia (L.) Urb. Afr. J. Agric. Res. 2014, 9, 846-853.

41. Nikaido, H. Molecular basis of bacterial outer membrane permeability revisited. Microbiol. Mol. Biol. Rev. 2003, 67, 593-656. [CrossRef] [PubMed]

42. Olayede, G.K. Toxicity, antimicrobial and antioxidant activities of methyl salicylate dominated essential oils of Laporte aaestuans (Gaud). Arab. J. Chem. 2011. [CrossRef]

43. Bigos, M.; Wasiela, M.; Kalemba, D.; Sienkiewicz, M. Antimicrobial activity of geranium oil against clinical strains of Staphylococcus aureus. Molecules 2012, 17, 10276-10291. [CrossRef] [PubMed]

44. Lopez-Romero, J.C.; González-Ríos, H.; Borges, A.; Simões, M. Antibacterial effects and mode of action of selected essential oils components against Escherichia coli and Staphylococcus aureus. Evid.-Based Complement. Altern. Med. 2015, 795435. [CrossRef]

45. Oztürk, M.; Duru, M.E.; Aydoğmuş-Oztürk, F.; Harmandar, M.; Mahliçli, M.; Kolak, U.; Ulubelen, A. GC-MS analysis and antimicrobial activity of essential oil of Stachys cretica subsp. smyrnaea. Nat. Prod. Commun. 2009, $4,109-114$.

46. Viollon, C.; Chaumont, J.P. Antifungal properties of essential oils and their main components upon Cryptococcus neoformans. Mycopathologia 1994, 128, 151-153. [CrossRef] [PubMed]

47. Arıdoğan, B.C.; Baydar, H.; Kaya, S.; Demirci, M.; Özbaşar, D.; Mumcu, E. Antimicrobial activity and chemical composition of some essential oils. Arch. Pharm. Res. 2002, 25, 860-865. [CrossRef] [PubMed] 
48. Kloucek, P.; Smid, J.; Frankova, A.; Kokoska, L.; Valterova, I.; Pavela, R. Fast screening method for assessment of antimicrobial activity of essential oils in vapor phase. Food Res. Int. 2012, 47, 161-165. [CrossRef]

49. Muroi, H.; Kubo, A.; Kubo, I. Antimicrobial activity of cashew apple flavor compounds. J. Agric. Food Chem. 1993, 41, 1106-1109. [CrossRef]

(C) 2015 by the authors; licensee MDPI, Basel, Switzerland. This article is an open access article distributed under the terms and conditions of the Creative Commons by Attribution (CC-BY) license (http://creativecommons.org/licenses/by/4.0/). 